\title{
Heavy Metals in Water and Sediment: A Case Study of Tembi River
}

\author{
Saeed Shanbehzadeh, ${ }^{1}$ Marzieh Vahid Dastjerdi, ${ }^{2}$ \\ Akbar Hassanzadeh, ${ }^{3}$ and Toba Kiyanizadeh ${ }^{1}$ \\ ${ }^{1}$ Health Center of Masjed Soleman, 8 Bangle Avenue, Masjed Soleman, Iran \\ ${ }^{2}$ Environment Research Center, School of Health, Isfahan University of Medical Sciences, Hezar Jerib Avenue, Isfahan, Iran \\ ${ }^{3}$ Faculty of Health, Isfahan University of Medical Sciences, Hezar Jerib Avenue, Isfahan, Iran \\ Correspondence should be addressed to Marzieh Vahid Dastjerdi; vahid@hlth.mui.ac.ir
}

Received 18 September 2013; Revised 6 November 2013; Accepted 11 November 2013; Published 29 January 2014

Academic Editor: Pam R. Factor-Litvak

Copyright (C) 2014 Saeed Shanbehzadeh et al. This is an open access article distributed under the Creative Commons Attribution License, which permits unrestricted use, distribution, and reproduction in any medium, provided the original work is properly cited.

This study was carried out to examine heavy metals concentration in water and sediment of upstream and downstream of the entry of the sewage to the Tembi River, Iran. Samples were collected from upstream and downstream and were analyzed for $\mathrm{Cd}, \mathrm{Cr}$, $\mathrm{Cu}$, $\mathrm{Fe}, \mathrm{Pb}, \mathrm{Ni}$, and $\mathrm{Zn}$ by atomic absorption spectrophotometer. The results indicated that the average concentration of the metals in water and sediment on downstream was more than that of upstream. The comparison of the mean concentrations of heavy metals in water of the Tembi River with drinking water standards and those in the water used for agriculture suggests that the mean concentration of $\mathrm{Cu}$ and $\mathrm{Zn}$ lies within the standard range for drinking water and the mean concentration of $\mathrm{Mn}, \mathrm{Zn}$, and $\mathrm{Pb}$ lies within the standard range of agricultural water. The highest average concentration on downstream for $\mathrm{Pb}$ in water and for $\mathrm{Mn}$ in sediment was 1.95 and $820.5 \mathrm{ppm}$, respectively. Also, the lowest average concentration on upstream was identified for Cd in water and sediment 0.07 and $10 \mathrm{ppm}$, respectively. With regard to the results, it gets clear that using the water for recreational purposes, washing, and fishing is detrimental to human health and the environment.

\section{Introduction}

The entry of contaminants into the environment due to human and natural activities is one of the most important issues facing today's communities. Due to the industrial and economic growth and the production of a variety of compounds and chemicals followed by increased consumption man makes some unwanted pollutants, many of which cause serious problems and risks for the environment and for man himself. The most important natural resources of environmental pollution are soil and rock weathering and natural events such as earthquakes and floods [1]. The entry of municipal, industrial, and agricultural waste into the environment is another way of the environment pollution by human. Water resources are among the most critical resources. The importance of water resources, particularly surface waters (rivers), in meeting the water needs of humans, animals and industries indicates the essential need to protect them against contamination. As municipal, industrial, and agricultural waste enters the water, biological and chemical contaminants including heavy metals also enter water resources. Although some of these metals are essential as micronutrients, their high concentration in the food chain can cause toxicity and environmental impacts and endanger aquatic ecosystems and their users [2,3]. Rivers as water resources, not only in terms of drinking water supply but also in terms of their function in recreational and sport activities such as water sports and fishing, are very important to man's health. The investigation of the entry sources, effects, and control of pollutants in rivers has, therefore, always been one of the research topics of environmental scientists. Tembi River, located in the outskirts of Masjed Soleyman, Iran, is open to untreated municipal sewage, runoff, abattoir wastewater, and leachate of solid wastes around it [4]. Regarding the above-mentioned issues and due to the fact that it is a place for the migration of birds in cold seasons as well as for public promenade, swimming, and 
TABLE 1: Variations of average of heavy metals concentration in Tembi River water in different seasons (mg/L).

\begin{tabular}{|c|c|c|c|c|c|}
\hline \multirow{2}{*}{ Heavy metals } & \multirow{2}{*}{ Sampling point } & \multicolumn{4}{|c|}{ Sampling time } \\
\hline & & Summer 2011 & Autumn 2011 & Winter 2011 & Spring 2012 \\
\hline \multirow{2}{*}{$\mathrm{Cd}$} & 1 & $0.07 \pm 0.010$ & $0.12 \pm 0.700$ & $0.24 \pm 0.002$ & $0.25 \pm 0.030$ \\
\hline & 2 & $0.1 \pm 0.006$ & $0.26 \pm 0.010$ & $0.30 \pm 0.010$ & $0.35 \pm 0.050$ \\
\hline \multirow{2}{*}{$\mathrm{Cr}$} & 1 & $0.13 \pm 0.010$ & $0.29 \pm 0.005$ & $0.16 \pm 0.010$ & $0.17 \pm 0.010$ \\
\hline & 2 & $0.25 \pm 0.010$ & $0.40 \pm 0.05$ & $0.31 \pm 0.060$ & $0.58 \pm 0.005$ \\
\hline \multirow{2}{*}{$\mathrm{Cu}$} & 1 & $0.26 \pm 0.020$ & $0.45 \pm 0.080$ & $0.56 \pm 0.010$ & $0.62 \pm 0.010$ \\
\hline & 2 & $0.40 \pm 0.01$ & $0.54 \pm 0.050$ & $0.63 \pm 0.010$ & $0.71 \pm 0.010$ \\
\hline \multirow{2}{*}{$\mathrm{Fe}$} & 1 & $0.24 \pm 0.010$ & $0.18 \pm 0.010$ & $0.82 \pm 0.040$ & $1.1 \pm 0.005$ \\
\hline & 2 & $0.26 \pm 0.020$ & $0.28 \pm 0.030$ & $1.1 \pm 0.050$ & $1.87 \pm 0.030$ \\
\hline \multirow{2}{*}{$\mathrm{Mn}$} & 1 & $0.07 \pm 0.003$ & $0.09 \pm 0.001$ & $0.81 \pm 0.01$ & $0.82 \pm 0.010$ \\
\hline & 2 & $1.00 \pm 0.007$ & $1.25 \pm 0.030$ & $1.40 \pm 0.020$ & $0.91 \pm 0.020$ \\
\hline \multirow{2}{*}{$\mathrm{Ni}$} & 1 & $0.16 \pm 0.01$ & $0.40 \pm 0.050$ & $0.52 \pm 0.010$ & $0.83 \pm 0.02$ \\
\hline & 2 & $0.50 \pm 0.050$ & $0.75 \pm 0.010$ & $0.65 \pm 0.070$ & $0.80 \pm 0.020$ \\
\hline \multirow{2}{*}{$\mathrm{Pb}$} & 1 & $0.59 \pm 0.06$ & $1.45 \pm 0.030$ & $0.81 \pm 0.080$ & $1.64 \pm 0.020$ \\
\hline & 2 & $1.80 \pm 0.070$ & $0.85 \pm 0.070$ & $1.02 \pm 0.010$ & $1.91 \pm 0.030$ \\
\hline \multirow{2}{*}{$\mathrm{Zn}$} & 1 & $0.12 \pm 0.000$ & $0.23 \pm 0.005$ & $0.34 \pm 0.000$ & $0.11 \pm 0.000$ \\
\hline & 2 & $0.20 \pm 0.010$ & $0.29 \pm 0.005$ & $0.51 \pm 0.020$ & $0.40 \pm 0.000$ \\
\hline
\end{tabular}

1: upstream; 2: downstream.

fishing the present study was thus carried out to investigate the concentration of heavy metals such as copper, zinc, lead, chromium, cadmium, nickel, and manganese due to the discharge of sewage of Masjed Soleyman into this river.

\section{Materials and Methods}

2.1. Sample Collection. After determining the location of the sampling points before and after the entry of the sewage, 96 samples (48 water samples and 48 sediment samples) were collected by grab method for 1-year period; four samples of water and four samples of sediment were collected in each month EE and 3 liters of water was collected in each of sampling from below the water surface and $30 \mathrm{~g}$ of sediment samples from a depth of $20 \mathrm{~cm}$ under the bed river were collected [5]. Samples of water acidified with nitric acid $(\mathrm{PH}=2)$ along with other samples were transferred to the laboratory.

2.2. Sediment Samples Preparation. $30 \mathrm{~g}$ of sediment samples was dried at $105^{\circ} \mathrm{C}$. One gram of each sample was weighed carefully and $5 \mathrm{~mL}$ of concentrated nitric acid (Merck, 99.99\%) was added to each sample. The sample, then, was heated up to $80^{\circ} \mathrm{C}$ until near dryness. The addition of acid and the process of heating were repeated two more times [6]. An amount of water was added to the residual material. The suspension was filtered (Whatman filter Merck, $0.45 \mu \mathrm{m}$ ) and the filtrate was diluted by deionized water to a final volume of $50 \mathrm{~mL}$.

2.3. Water Samples Preparation. Three liters of each collected water sample was first concentrated on a sandy oven at $80^{\circ} \mathrm{C}$ until the volume reached $50 \mathrm{~mL}$. Then $4 \mathrm{~mL}$ concentrated sulfuric acid (Merck, 98\%) was added to each sample and Digested by digesdahl apparatus for 3 minutes. The $10 \mathrm{~mL}$ hydrogen peroxide (Merck, 30\%) was then added and heated until oxidation was completed. After cooling, each sample filtered by filter (Whatman filter Merck, $0.45 \mu \mathrm{m}$ ). The filtrate was diluted by deionized water to a final volume of $50 \mathrm{~mL}$.

2.4. Samples Analysis. The prepared samples were analyzed by a Graphite furnace atomic absorption spectrometry (GFAAS, Model AAnalyst300) to determine the metals [6].

2.5. Statistical Analysis (Analysis of Variance, t-Test, and Least Significant Differences Test That Means "LSD"). It was conducted to determine the difference of metal ion concentrations among the water and sediment in upstream and downstream of Tembi River in different seasons. A $P$ value $\leq$ 0.05 was considered significant. The correlation analysis was also carried out to determine the relationship between the concentration of metal ions in water and sediment.

\section{Results}

The mean concentration of $\mathrm{Cd}, \mathrm{Cr}, \mathrm{Cu}, \mathrm{Fe}, \mathrm{Pb}$, Nis and $\mathrm{Zn}$ in water and sediment samples before and after the sewage entry into the Tembi River is presented with their standard deviations in Tables 1 and 2.

\section{Discussion}

The results of the analysis of water and sediment samples in upstream and downstream of the river revealed that the mean concentration of $\mathrm{Cd}, \mathrm{Cr}, \mathrm{Cu}, \mathrm{Fe} \mathrm{Mn}, \mathrm{Pb}$, and $\mathrm{Zn}$ in the downstream water was higher than that in the upstream water in different seasons $(P<0.001)$. Table 1 indicates the effect of the entry of sewage (including untreated municipal sewage, runoff, abattoir wastewater, and leachate of solid wastes 
TABLE 2: Variations of average of heavy metals concentration in Tembi River sediments in different seasons (mg/kg).

\begin{tabular}{|c|c|c|c|c|c|}
\hline \multirow{2}{*}{ Heavy metals } & \multirow{2}{*}{ Sampling point } & \multicolumn{4}{|c|}{ Sampling time } \\
\hline & & Summer 2011 & Autumn 2011 & Winter 2011 & Spring 2012 \\
\hline \multirow{2}{*}{$\mathrm{Cd}$} & 1 & $14 \pm 0.7$ & $10 \pm 0.5$ & $10 \pm 0.5$ & $24 \pm 1.00$ \\
\hline & 2 & $40 \pm 1.1$ & $20 \pm 1.5$ & $14 \pm 0.5$ & $24 \pm 0.5$ \\
\hline \multirow{2}{*}{$\mathrm{Cr}$} & 1 & $57 \pm 1.5$ & $40 \pm 0.5$ & $28 \pm 2.0$ & $42 \pm 1.1$ \\
\hline & 2 & $74 \pm 0.5$ & $70 \pm 2.0$ & $11 \pm 1.0$ & $67 \pm 4.0$ \\
\hline \multirow{2}{*}{$\mathrm{Cu}$} & 1 & $70 \pm 1.1$ & $50 \pm 1.0$ & $37 \pm 1.5$ & $49 \pm 1.0$ \\
\hline & 2 & $100 \pm 2.6$ & $66 \pm 1.0$ & $40 \pm 1.7$ & $54 \pm 1.0$ \\
\hline \multirow{2}{*}{$\mathrm{Fe}$} & 1 & $250 \pm 6.0$ & $230 \pm 1.0$ & $220 \pm 1.0$ & $230 \pm 0.5$ \\
\hline & 2 & $280 \pm 3.0$ & $234 \pm 2.0$ & $210 \pm 0.5$ & $233 \pm 1.05$ \\
\hline \multirow{2}{*}{$\mathrm{Mn}$} & 1 & $715 \pm 1.00$ & $310 \pm 16$ & $310 \pm 11$ & $302 \pm 12$ \\
\hline & 2 & $820 \pm 2.5$ & $310 \pm 5.0$ & $278 \pm 5.0$ & $341 \pm 9.0$ \\
\hline \multirow{2}{*}{$\mathrm{Ni}$} & 1 & $107 \pm 2.0$ & $63 \pm 3.2$ & $52 \pm 2.9$ & $129 \pm 11$ \\
\hline & 2 & $150 \pm 3.6$ & $80 \pm 7.6$ & $87 \pm 2.5$ & $143 \pm 7.0$ \\
\hline \multirow{2}{*}{$\mathrm{Pb}$} & 1 & $240 \pm 3.4$ & $198 \pm 2.3$ & $141 \pm 4.0$ & $151 \pm 5.0$ \\
\hline & 2 & $270 \pm 0.5$ & $236 \pm 2.0$ & $178 \pm 3.3$ & $210 \pm 2.0$ \\
\hline \multirow{2}{*}{$\mathrm{Zn}$} & 1 & $54 \pm 2.0$ & $30 \pm 1.5$ & $24 \pm 2.0$ & $32 \pm 1.0$ \\
\hline & 2 & $74 \pm 2.0$ & $30 \pm 1.5$ & $21 \pm 2.0$ & $38 \pm 1.0$ \\
\hline
\end{tabular}

1: upstream; 2: downstream.

around the river) on Tembi River. In a similar research Wogu and Okaka [7] investigated 9 similar metals in the Warri River in Nigeria, which receives the industrial, agricultural, and urban sewage, and showed that the concentration of $\mathrm{Cd}, \mathrm{Cr}$, $\mathrm{Mn}$, and $\mathrm{Ni}$ in this river is higher than the stated standard level for it, and that its water is harmful to the public health and hygiene [7].

It is to be noted that the mean concentration of metals in water in downstream and upstream has increased from Summer 2011 to Spring 2012. Pb has had the highest mean concentration of $1.95 \pm 0.09 \mathrm{mg} / \mathrm{L}$ in downstream and $\mathrm{Cd}$ has had the lowest concentration of $0.07 \pm 0.001 \mathrm{mg} / \mathrm{L}$ in upstream area. The seasonal distribution of the mean concentrations of metal of $\mathrm{Cd}, \mathrm{Cr}, \mathrm{Cu}, \mathrm{Fe}, \mathrm{Mn}, \mathrm{Ni}, \mathrm{Pb}$, and $\mathrm{Zn}$ in Tembi River water have been shown to be as follows (the maximum amounts are related to hot seasons):

$$
\begin{aligned}
& (0.07-0.35,0.13-0.58,0.26-0.71,0.24-1.87, \\
& 0.07-0.91,0.16-0.8,0.59-1.91,0.12-0.4) \mathrm{mg} / \mathrm{L} .
\end{aligned}
$$

These results show the effect of dry seasons and water evaporation on concentration increase of heavy metals in water. These results were similar to results of Obasohan and Eguavoen and Ahmed et al. [8] researches [8, 9]. Obasohan and Eguavoen [9] have stated in their research that dry seasons affect the accumulation of heavy metals in water and its reared fish. In a similar study, Ahmed et al. [8] investigated the distribution of heavy metals concentration in the Buriganga River in Nigeria and found out that the seasonal distribution of $\mathrm{Cd}, \mathrm{Cr}, \mathrm{Cu}, \mathrm{Ni}$, and $\mathrm{Pb}$ varies seasonally as follows:

$$
\text { (7.08-12.33, 489.27-645, 107.38-201.29, }
$$

They have also stated that the maximum and minimum concentrations are those of $\mathrm{Ni}$ and $\mathrm{Cd}$ [8], respectively.

The comparison of the mean concentrations of heavy metals in the Tembi River water with the standard value in drinking water [10] and those in the water used for agriculture [11] for aquatic life [12] and surface water standards [13] suggests that the mean concentration of $\mathrm{Cu}$ lies within the standard range for drinking water and the mean concentrations of $\mathrm{Mn}$ and $\mathrm{Cd}$ lie within the standard range of agricultural water. Only do the mean concentrations of $\mathrm{Zn}$ lie within the standard range for all three kinds of water. In general, Tembi River water is not suitable for drinking and aquatic life. Mean concentrations of $\mathrm{Cd}, \mathrm{Cr}, \mathrm{Mn}$, and $\mathrm{Pb}$ were higher than surface water standards (Table 3 ).

The mean concentrations of metals in the sediments of the Tembi River downstream have increased in comparison with those in its upstream. The maximum and minimum levels of concentration are related to $\mathrm{Mn}$ in downstream and $\mathrm{Cd}$ in upstream areas, respectively (Table 2). Regarding the rise in the concentrations of these metals in downstream water, the higher concentrations in downstream sediment are very reasonable. In fact; increased heavy metals concentration in water in downstream lead to increasing of their concentration in sediment in downstream. In a similar study Kowsari and Naei [14] stated that physicochemical characteristics of water affect the precipitation of these elements in sediment.

The mean concentration of metals in the sediments of the river upstream, where the sewage enters Tembi River, changes similarly in four seasons. In other words, the average concentration of metals in sediments in Autumn and Winter is lower than that in Summer. These amounts rise again when Summer starts. The amounts of heavy metals in sediment varied seasonally as follows:

$$
\text { Summer }>\text { Autumn }>\text { Winter }>\text { Spring. }
$$


TABLE 3: Comparison of average of heavy metals concentration in upstream and downstream of Tembi River with guideline for water (mg/L) [10-13].

\begin{tabular}{|c|c|c|c|c|c|c|c|c|c|c|c|c|c|c|c|c|}
\hline \multirow{2}{*}{$\frac{\text { Heavy metals }}{\text { sampling point }}$} & \multicolumn{2}{|c|}{$\mathrm{Cd}$} & \multicolumn{2}{|c|}{$\mathrm{Cr}$} & \multicolumn{2}{|c|}{$\mathrm{Cu}$} & \multicolumn{2}{|c|}{$\mathrm{Fe}$} & \multicolumn{2}{|c|}{$\mathrm{Mn}$} & \multicolumn{2}{|c|}{$\mathrm{Ni}$} & \multicolumn{2}{|c|}{$\mathrm{Pb}$} & \multicolumn{2}{|c|}{$\mathrm{Zn}$} \\
\hline & 1 & 2 & 1 & 2 & 1 & 2 & 1 & 2 & 1 & 2 & 1 & 2 & 1 & 2 & 1 & 2 \\
\hline Average & 0.17 & 0.25 & 0.19 & 0.29 & 0.47 & 0.57 & 0.56 & 0.96 & 0.45 & 0.94 & 0.48 & 0.68 & 1.13 & 1.4 & 0.2 & 0.35 \\
\hline Drinking water standards & \multicolumn{2}{|c|}{0.005} & \multicolumn{2}{|c|}{0.1} & \multicolumn{2}{|c|}{1.3} & \multicolumn{2}{|c|}{0.3} & \multicolumn{2}{|c|}{0.05} & \multicolumn{2}{|c|}{-} & \multicolumn{2}{|c|}{0.00} & \multicolumn{2}{|c|}{5.00} \\
\hline Irrigation water standards & \multicolumn{2}{|c|}{0.01} & \multicolumn{2}{|c|}{0.1} & \multicolumn{2}{|c|}{0.2} & \multicolumn{2}{|c|}{ - } & \multicolumn{2}{|c|}{2.00} & \multicolumn{2}{|c|}{0.2} & \multicolumn{2}{|c|}{5.00} & \multicolumn{2}{|c|}{2.00} \\
\hline Aquatic life standards & \multicolumn{2}{|c|}{0.01} & \multicolumn{2}{|c|}{0.05} & \multicolumn{2}{|c|}{0.05} & \multicolumn{2}{|c|}{ - } & \multicolumn{2}{|c|}{0.1} & \multicolumn{2}{|c|}{ - } & \multicolumn{2}{|c|}{0.05} & \multicolumn{2}{|c|}{$<0.1$} \\
\hline Surface water standards & \multicolumn{2}{|c|}{0.01} & \multicolumn{2}{|c|}{0.16} & \multicolumn{2}{|c|}{ - } & \multicolumn{2}{|c|}{-} & & & & & & & & - \\
\hline
\end{tabular}

1: upstream; 2: downstream.

TABLE 4: Comparison of average of heavy metals concentration in upstream and downstream sediments with guideline for sediments (mg/kg) [15-17].

\begin{tabular}{lccccccccccccccccc}
\hline Heavy metals & \multicolumn{2}{c}{$\mathrm{Cd}$} & \multicolumn{2}{c}{$\mathrm{Cr}$} & \multicolumn{2}{c}{$\mathrm{Cu}$} & \multicolumn{2}{c}{$\mathrm{Fe}$} & \multicolumn{2}{c}{$\mathrm{Mn}$} & \multicolumn{2}{c}{$\mathrm{Ni}$} & \multicolumn{2}{c}{$\mathrm{Pb}$} \\
\hline Sampling point & 1 & 2 & 1 & 2 & 1 & 2 & 1 & 2 & 1 & 2 & 1 & 2 & 1 & 2 & 1 & 2 \\
Average & 14.5 & 24.5 & 42 & 55.5 & 51.5 & 65 & 232 & 239 & 409 & 437 & 87.8 & 115 & 182 & 223 & 35 & $\mathbf{4 1}$ \\
Fresh water sediments guideline & 0.99 & 43.4 & 31.6 & & - & & - & & 22.7 & 35.8 & $\mathbf{1 2 1}$ \\
Marin sediments & 5.1 & 260 & 390 & & - & & - & & - & & 450 & $\mathbf{4 1 0}$ \\
\hline
\end{tabular}

1: upstream; 2: downstream.

The cause of these changes was high rain in Autumn and Winter which gives rise to flow of the water in the river. Due to the turbulence created by increase of flow, some sediments and heavy metals inside them are displaced and carried away from the river bed. As Summer starts, the rise in temperature and evaporation and the end of the rain period cause the rise in heavy metals concentration in water and finally in sediments because metal ions transfer from water to sediment. The seasonal variation of distribution of $\mathrm{Cd}, \mathrm{Cr}$, $\mathrm{Cu}, \mathrm{Fe}, \mathrm{Mn}, \mathrm{Ni}, \mathrm{Pb}$, and $\mathrm{Zn}$ in the sediments is as follows:

$$
\begin{aligned}
& (10-40,11-74,37-100,210-280,278-820, \\
& 52-150,641-270,21-74) \mathrm{mg} / \mathrm{kg} .
\end{aligned}
$$

In this regard Mor et al. [18], in a survey of pollution that resulted from oil wells and heavy metals in the Tembi River sediments, announced the amounts of variation in the concentrations of $\mathrm{Cd}, \mathrm{Cr}, \mathrm{Cu}, \mathrm{Ni}, \mathrm{Pb}$, and $\mathrm{Zn}$ as follows:

$$
\begin{aligned}
& \quad(2.39-6.5,70-130,16-74,11-33 \text {, } \\
& \qquad 56-120,50-236) \mathrm{mg} / \mathrm{kg} \text {. } \\
& \text { Ahmed et al. [8] announced the seasonal } \\
& \text { se concentrations of Cd, Cr, Cu, Ni, and } \\
& (2.36-4.25,118.63-218.19,21.75-32.54 \text {, } \\
& 147.06-258.17,64.71-77.13) \mathrm{mg} / \mathrm{kg} \text {. }
\end{aligned}
$$

Also, Ahmed et al. [8] announced the seasonal distribution of the concentrations of $\mathrm{Cd}, \mathrm{Cr}, \mathrm{Cu}, \mathrm{Ni}$, and $\mathrm{Pb}$ in the sediments of the Buriganga River as follows:

The comparison of mean concentrations of the these metals with the standards for fresh water sediments indicates that, except $\mathrm{Zn}$, the mean concentrations of $\mathrm{Cd}, \mathrm{Cr}, \mathrm{Cu}$, $\mathrm{Ni}$, and $\mathrm{Pb}$ were higher than the standards for fresh water sediments $[15,16]$ while only the mean concentrations of $\mathrm{Cd}$ in marine sediments [17] were higher than the standards
(Table 4). However, due to increased metals concentration in the sediments of Tembi River, the rise of concentrations of heavy metals, in comparison with guideline in sediments, is expected in future.

\section{Concluding Remarks}

Based on the above-mentioned points, it is clear that the water and sediments of the Tembi River were contaminated by heavy metals and, therefore, using this water for recreational purposes, washing, and fishing is detrimental to human health and the environment. It is, thus, necessary to take serious and essential measures to control the entry of the sewage, treat it before entering the river, manage the quality of water and the sediments of the river, and utilize water for various purposes.

\section{Conflict of Interests}

The authors declare that there is no conflict of interests regarding the publication of this paper.

\section{Acknowledgments}

This study was supported in 2011-2012 by the Environment Research Center, Isfahan University of Medical Sciences, Iran (Grant no. 290306). The authors are grateful to Dr. Hossin Vahid Dastjerdi and Dr. Mahnaz Nikaeen for paper edition.

\section{References}

[1] F. R. Espinoza-Quiñones, C. E. Zacarkim, S. M. Palacio et al., "Removal of heavy metal from polluted river water using aquatic macrophytes Salvinia sp.," Brazilian Journal of Physics, vol. 35, no. 3, pp. 744-746, 2005. 
[2] P. C. Prabu, "Impact of heavy metal contamination of Akaki river of Ethiopia on soil and metal toxicity on cultivated vegetable crops," Electronic Journal of Environmental, Agricultural and Food Chemistry, vol. 8, no. 9, pp. 818-827, 2009.

[3] "Assessment of heavy metals in some dumps of copper mining and plants in Mirdita Area, Albania," in Proceedings of the 5th International Scientific Conference on Water, Climate and Environment, S. Kane, P. Lazo, and A. Vlora, Eds., Ohrid, Macedonia, 2012.

[4] "The effect of Masjed soleiman sewage on water quality of Tembi River and water quality management guidelines presented it," in Proceedings of the 7th International River engineering Conference, N. Ghazizadeh, M. Shariat, and N. Jafarzadeh, Eds., Shahid Chamran University, Ahwaz, Iran, 2006.

[5] J. Pandey and U. Pandey, "Accumulation of heavy metals in dietary vegetables and cultivated soil horizon in organic farming system in relation to atmospheric deposition in a seasonally dry tropical region of India," Environmental Monitoring and Assessment, vol. 148, no. 1-4, pp. 61-74, 2009.

[6] A. D. Eaton and M. A. H. Franson, Standard Methods for the Examination of Water \& Waste Water, American Public Health Association, 2005.

[7] M. D. Wogu and C. E. Okaka, "Pollution studies on Nigerian rivers: heavy metals in surface water of warri river, Delta State," Journal of Biodiversity and Environmental Sciences, vol. 1, no. 3, pp. 7-12, 2011.

[8] M. K. Ahmad, S. Islam, S. Rahman, M. R. Haque, and M. M. Islam, "Heavy metals in water, sediment and some fishes of buriganga river, Bangladesh," International Journal of Environmental Research, vol. 4, no. 2, pp. 321-332, 2010.

[9] E. E. Obasohan and O. I. Eguavoen, "Seasonal variations of bioaccumulation of heavy metals in a freshwater fish (Erpetoichthys calabaricus) from Ogba River, Benin City, Nigeria," Indian Journal of Animal Research, vol. 42, no. 3, pp. 171-179, 2008.

[10] A. Brenner and E. J. Hoekstra, "Drinking water quality standards and regulations," in Best Practice Guide on Metals Removal from Drinking Water by Treatment, p. 1, 2012.

[11] G. Fipps, "Irrigation water quality standards and salinity management strategies," 2003, http://repository.tamu.edu/handle/ 1969.1/87829.

[12] Y. Wang, P. Chen, R. Cui, W. Si, Y. Zhang, and W. Ji, "Heavy metal concentrations in water, sediment, and tissues of two fish species (Triplohysa pappenheimi, Gobio hwanghensis) from the Lanzhou section of the Yellow River, China," Environmental Monitoring and Assessment, vol. 165, no. 1-4, pp. 97-102, 2010.

[13] New Jersey Water Supply, "Surface water quality and pollutant loadings," A Technical Report for the Raritan Basin Watershed Management Project, 2002.

[14] "Survey of the source and amount of pollutants concentration of heavy metal in Tembi River and Bohlol Lake," in Proceedings of the 1st Conference on Geological and Environmental and Medical, S. Kosari and M. Vanae, Eds., Tehran, Iran, 2007.

[15] D. D. MacDonald, C. G. Ingersoll, and T. A. Berger, "Development and evaluation of consensus-based sediment quality guidelines for freshwater ecosystems," Archives of Environmental Contamination and Toxicology, vol. 39, no. 1, pp. 20-31, 2000.

[16] G. A. Burton Jr., "Sediment quality criteria in use around the world," Limnology, vol. 3, no. 2, pp. 65-76, 2002.

[17] E. R. Long, M. Dutch, V. Partridge, S. Weakland, and K. Welch, "Revision of sediment quality triad indicators in Puget Sound
(Washington, USA): I. A sediment chemistry Index and targets for mixtures of toxicants," Integrated Environmental Assessment and Management, vol. 9, no. 1, pp. 31-49, 2013.

[18] "Survey of the pollution of the fountain of oil and heavy metals in the sediments of Tembi River of Masjed soleiman," in Proceedings of the 20th Deafness Which Since His Gathering Earth Sciences and the 13th Conference Geological Society of Iran, F. Mor, Z. Yavarsad, and S. A. Hesam, Eds., Tehran, Iran, 2009. 


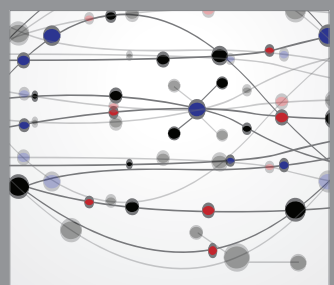

The Scientific World Journal
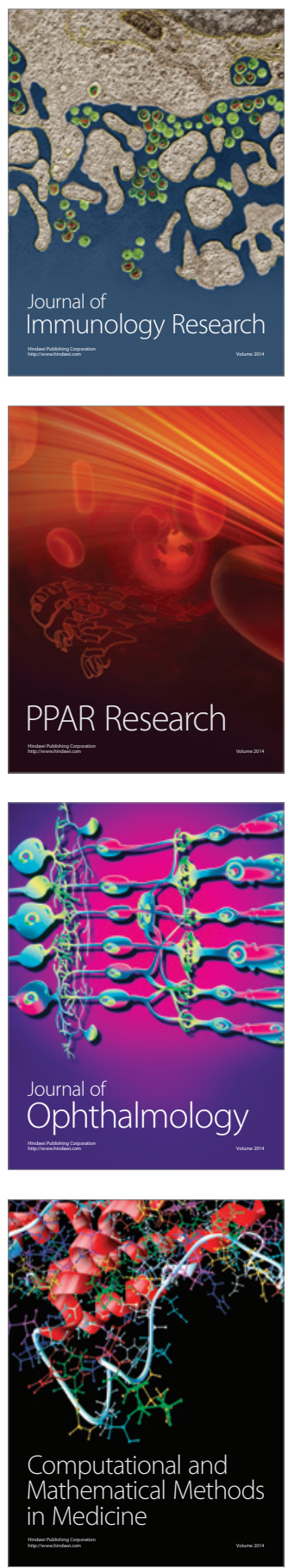

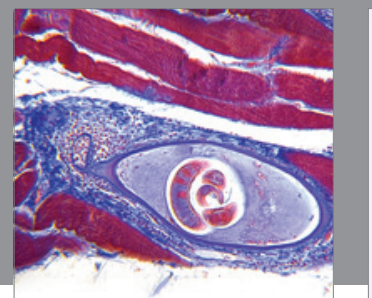

Gastroenterology

Research and Practice
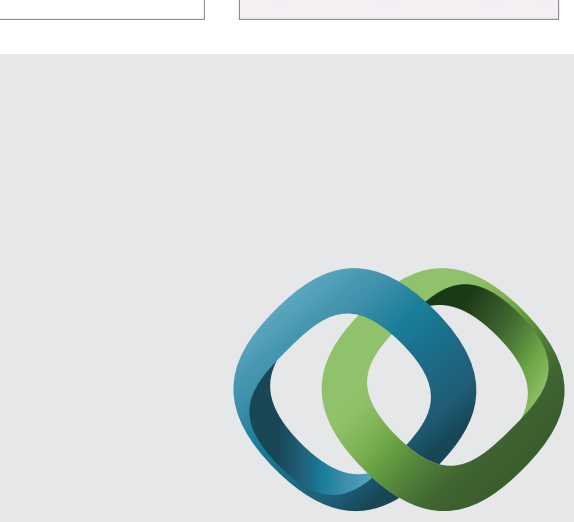

\section{Hindawi}

Submit your manuscripts at

http://www.hindawi.com
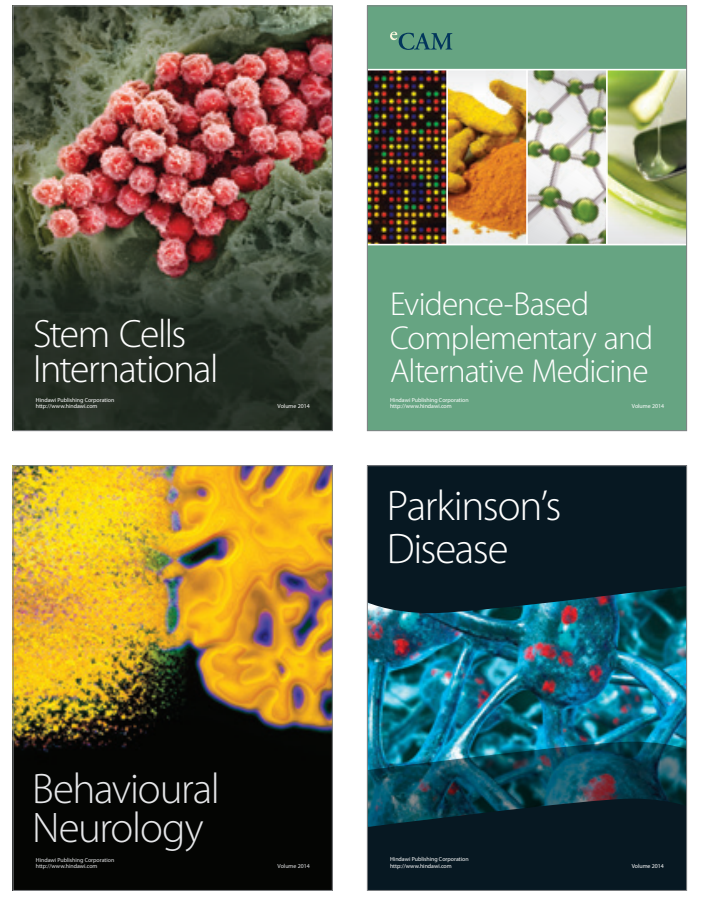
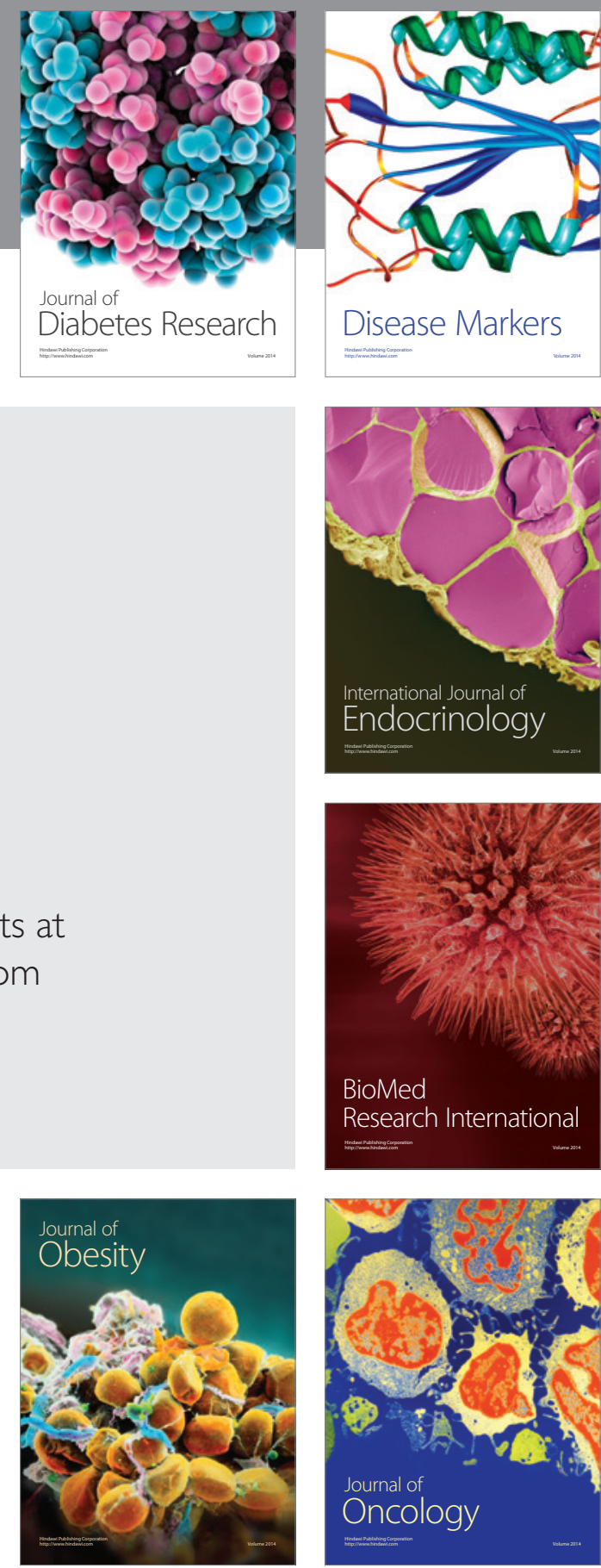

Disease Markers
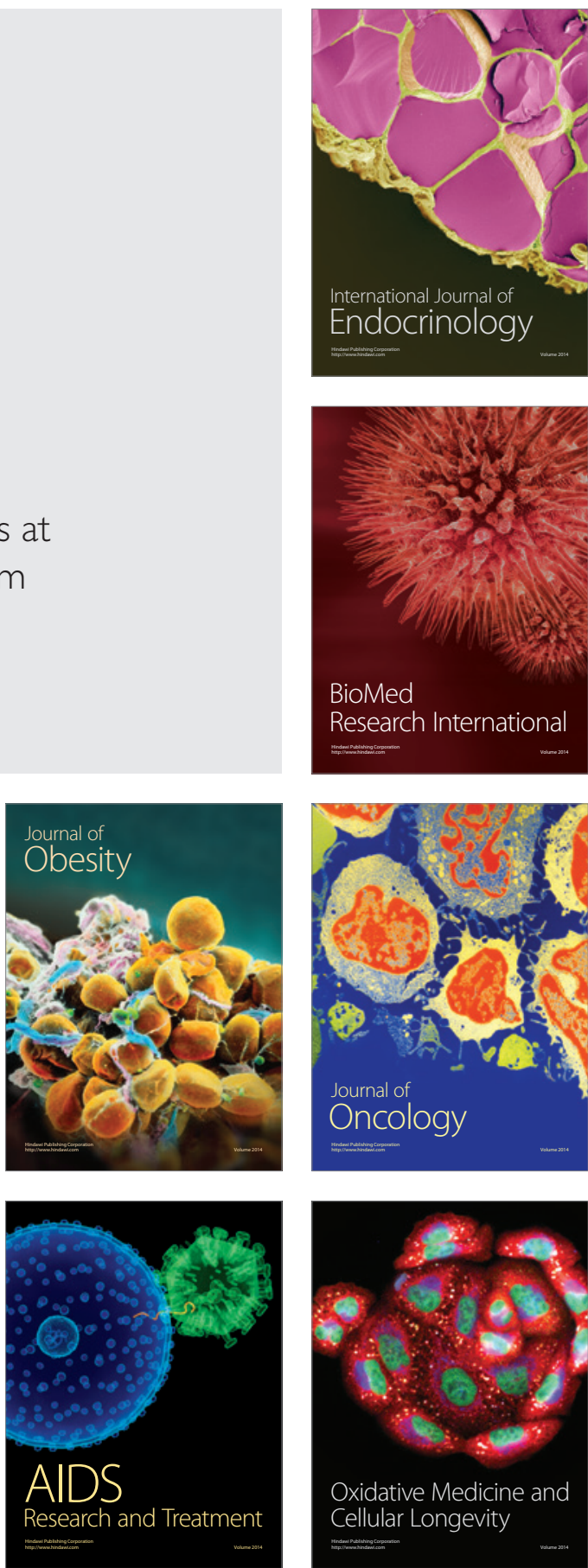